\title{
FAKTOR YANG MEMPENGARUHI PENERIMAAN OPINI AUDIT GOING CONCERN PADA PERUSAHAAN MANUFAKTUR YANG TERCATAT DI BURSA EFEK INDONESIA TAHUN 2011 - 2013
}

\author{
Theresia Dian Widyastuti \\ Universitas Katolik Atma Jaya \\ theresia.dian74@gmail.com
}

\begin{abstract}
This study was conducted to analyze the effect of liquidity, leverage, profitability, cash flow ratio, company size, growth, quality audits, and audit lag on the issue of going concern audit opinion of manufacturing companies listed in Indonesia Stock Exchange in year 2011 - 2013. The study was conducted on 72 samples of manufacturing companies selected. Binary logistic regression testing is used as statistical test. The results of this study showed that leverage and audit quality had significant impact on the issue of going concern audit opinion, whereas liquidity, profitability, cash flow ratio, company size, growth, and audit lag had no significant impact on the issue of going concern audit opinion.
\end{abstract}

Keyword: liquidity, leverage, profitabilitas, cash flow ratio, company size, company growth, quality audit, lag audit, audit opinion, going concern

\section{PENDAHULUAN}

\section{Latar Belakang Masalah}

Tujuan utama dari laporan keuangan adalah menyediakan informasi yang berguna dalam pembuatan keputusan terkait investasi, kredit, dan keputusan alokasi sumber daya lainnya mengingat adanya pemisahan antara pemilik dan manajemen yang dapat mengakibatkan konflik akibat perbedaan kepentingan (Jensen dan Meckling, 1976). Investor mengandalkan opini audit untuk landasan keputusan investasi (Levitt dalam Fanny dan Saputra, 2005). Untuk itu diperlukan peranan auditor independen dalam memeriksa kewajaran penyajian laporan keuangan perusahaan, termasuk untuk menilai dan menyatakan secara eksplisit mengenai kesangsian besar terhadap kemampuan perusahaan dalam mempertahankan kelangsungan hidupnya dalam waktu tidak lebih dari satu tahun sejak tanggal laporan audit. Beberapa penelitian sebelumnya menunjukkan faktor-faktor yang memengaruhi opini audit going concern antara lain kualitas audit, audit lag, opini audit tahun sebelumnya, dan auditor client tenure (Januarti, 2009), current ratio (Bruynseels dan Willekens, 2006; Rahayu, 2007; Masyitoh dan Adhariani, 2010), leverage (Rudyawan dan Badera, 2008), profitabilitas (Sartono, 2009; Behn et al., 2001; Hani dkk, 2003; Rahayu, 2007). Selain itu penelitian lainnya meneliti pengaruh rasio cash flow to total debt ratio (Mutchler, 1985; Mills dan Yamamura, 1998; Masyitoh dan Adhariani, 2010), ukuran perusahaan (Kevin et al., 2006; Ramadhany, 2005; Januarti dan Fitrianasari, 2008), pertumbuhan perusahaan (Altman, 1968; Fanny dan Saputra, 2005; Setyarno dkk., 2006), kualitas audit (DeAngelo, 1981; Setyarno dkk., 2006; Praptitorini dan Januarti, 2007). Audit lag 
juga diteliti oleh beberapa penelitian sebelumnya sebagai salah satu faktor yang memengaruhi opini audit going concern antara lain oleh Lennox( 2002), Putra (2010), Januarti (2009), Ramadhany (2004), Setyarno dkk.(2006), dan Praptitorini dan Januarti (2007).

Berdasarkah hasil yang masih beragam dari penelitian tersebut maka penelitian ini mencoba untuk menganalisis faktor-faktor yang memengaruhi penerimaan opini audit going concern yaitu likuiditas, leverage, profitabilitas, arus kas, ukuran perusahaan, pertumbuhan perusahaan, kualitas audit, dan audit lag.

\section{Rumusan Masalah}

Pokok permasalahan dalam penelitian ini adalah apakah likuiditas, leverage, profitabilitas, arus kas, ukuran perusahaan, pertumbuhan perusahaan, kualitas audit, dan audit lag memiliki pengaruh yang signifikan pada opini audit going concern perusahaan manufaktur yang tercatat di Bursa Efek Indonesia selama perioda 2011-2013?

\section{Tujuan Penelitian}

Tujuan penelitian ini adalah untuk memberikan bukti empiris mengenai pengaruh likuiditas, leverage, profitabilitas, arus kas, ukuran perusahaan, pertumbuhan perusahaan, kualitas audit, dan audit lag pada pemberian opini audit going concern perusahaan manufaktur yang tercatat di Bursa Efek Indonesia selama perioda 2011-2013.

\section{REVIEW LITERATUR DAN HIPOTESIS}

\section{Opini Audit}

Tujuan audit atas laporan keuangan oleh auditor independen adalah untuk menyatakan pendapat tentang kewajaran, dalam semua hal yang material, posisi keuangan, hasil usaha, perubahan ekuitas, dan arus kas sesuai dengan prinsip akuntansi yang berlaku umum di Indonesia. Baik dalam hal auditor menyatakan pendapat maupun menyatakan tidak memberikan pendapat, ia harus menyatakan apakah auditnya telah dilaksanakan berdasarkan standar auditing yang ditetapkan Ikatan Akuntan Indonesia (IAPI, 2012).

\section{Kemampuan Entitas dalam Mempertahankan Kelangsungan Hidup}

Belkaoui (2006) menyatakan bahwa entitas dikatakan going concern bila entitas dapat menjalankan terus operasinya dalam jangka waktu yang cukup lama untuk mewujudkan proyeknya, tanggung jawab, serta aktivitas-aktivitasnya yang tiada henti. Sebagai opini audit, istilah opini going concern menunjukkan auditor memiliki kesangsian mengenai kemampuan perusahaan untuk melanjutkan usahanya di masa mendatang (Rahayu, 2007)

\section{Likuiditas}

Likuiditas menggambarkan kemampuan perusahaan untuk memenuhi liabilitas jangka pendeknya yang jatuh tempo secara tepat waktu dan sering ditunjukkan oleh current ratio (Husnan dan Pudjiastuti, 2006). Rasio ini menunjukkan sebuah ukuran likuiditas yang cepat, mudah digunakan dan mampu menjadi indikator terbaik yaitu sampai sejauh mana klaim dari kreditor jangka pendek telah ditutupi oleh aset yang diharapkan dapat diubah menjadi kas dengan cukup cepat (Brigham \& Houston, 2009).

\section{Leverage}

Leverage, diproksikan dengan debt to equity ratio, menunjukkan proporsi atas penggunaan utang dibandingkan dengan penggunaan ekuitas dalam membiayai aktifitas perusahaan (Sartono, 2009). Rasio leverage yang tinggi menimbulkan keraguan akan kemampuan perusahaan untuk mempertahankan kelangsungan usahanya di masa depan karena sebagian besar dana yang diperoleh oleh perusahaan akan digunakan untuk membiayai utang dan dana 
untuk beroperasi akan semakin berkurang. Semakin besar debt ratio maka semakin besar kemungkinan auditor untuk memberikan opini audit going concern.

\section{Profitabilitas}

Profitabilits adalah laba yang diperoleh dari pendapatan bersih perusahaan dikurangi dengan beban yang dikeluarkan pada periode yang bersangkutan sehingga dapat menunjukkan kinerja perusahaan (Keown, 2004). Informasi tentang profitabilitas perusahaan membantu investor menilai secara tepat tingkat pengembalian yang akan didapat dari aktivitas investasinya apakah sesuai atau tidak dengan harapannya (Muhammad, 2007)

\section{Rasio Arus Kas}

Salah satu rasio arus kas yang dapat digunakan oleh auditor untuk menilai kemampuan perusahaan dalam melanjutkan usahanya adalah cash flow to total debt ratio (Mills dan Yamamura, 1998). Rasio ini diukur dengan membandingkan antara arus kas operasi dengan total kewajiban.

\section{Ukuran Perusahaan}

Perusahaan dengan total aset yang besar dianggap telah mencapai tahap kedewasaan, mengalami arus kas positif, dianggap memiliki prospek yang baik dalam jangka waktu yang relatif panjang, lebih stabil dan lebih mampu menghasilkan laba dibanding perusahaan dengan total aset yang kecil sehingga lebih mampu untuk menyelesaikan masalah keuangan yang dihadapi dan mempertahankan kelangsungan usahanya (Indriani, 2005; dalam Rachmawati dan Triatmoko, 2007).

\section{Pertumbuhan Perusahaan}

Pertumbuhanperusahaanmenggambarkan kemampuan perusahaan dalam mempertahankan kelangsungan usahanya dan seberapa baik perusahaan mempertahankan posisi ekonominya
(Weston dan Copeland, 1992; dalam Setyarno dkk., 2006). Semakin tinggi rasio pertumbuhan penjualan maka semakin kecil kemungkinan auditor untuk menerbitkan opini audit going concern (Setyarno dkk, 2006).

\section{Kualitas Audit}

Kualitas audit yang dipersepsikan oleh klien dikaitkan dengan apakah KAP yang dimaksud termasuk KAP skala besar dan memiliki afiliasi dengan KAP asing/ internasional atau di luar KAP skala besar memiliki insentif yang lebih besar untuk menghindari kritikan yang dapat menimbulkan kerusakan reputasi dibandingkan KAP skala kecil sehingga KAP besar memiliki insentif lebih untuk mendeteksi dan melaporkan masalah kelangsungan usaha kliennya (Chen et al., 2005). Hal ini terjadi karena auditor dari KAP besar dan berafiliasi internasional dianggap memiliki karakteristik yang dapat dikaitkan dengan kualitas, seperti pelatihan, pengakuan internasional, dan adanya peer review.

\section{Audit Lag}

Audit lag adalah rentang waktu penyelesaian pelaksanaan audit laporan keuangan tahunan yang diukur berdasarkan lamanya hari yang dibutuhkan untuk memperoleh laporan auditor independen atas audit laporan keuangan tahunan perusahaan sejak tanggal tahun tutup buku, yaitu per 31 Desember sampai tanggal yang tertera di laporan auditor independen (Rachmawati, 2008). Januarti dan Fitrianasari (2008), menemukan hubungan positif antara audit lag yang panjang dengan opini audit going concern. Auditor lebih banyak melakukan pengujian dan manajer melakukan negosiasi panjang ketika terdapat ketidakpastian kelangsungan usaha, dan auditor berharap bahwa perusahaan dapat mengatasi masalah yang dihadapi untuk menghindari dikeluarkannya opini audit going concern (Lennox, 2002). 


\section{Hipotesis Penelitian}

Mutchler (1985) melakukan analisis diskriminan dengan memasukkan enam rasio keuangan (Cash Flow/Total Liabilities, Current Asets/Current Liabilities, Net Worth/Total Liabilities, Total Long-term Liabilities/Total asets, dan Net Income Before Tax/Net Sales), item contrary information, mitigating factors, tren dan tipe opini tahun sebelumnya. Penelitian Mutchler (1985) menunjukkan bahwa bahwa pengetahuan mengenai rasio keuangan sangat berguna dalam memprediksi keputusan opini going concern. Persamaan penelitian ini dengan penelitian Mutchler (1985) adalah sama-sama meneliti current ratio dan cash flow/total liabilities.

\section{Pengaruh likuiditas pada opini audit going concern}

Likuiditas mengukur kemampuan perusahaan untuk memenuhi kewajiban jangka pendeknya dengan aset lancar yang dimilikinya. Rasio likuiditas dalam penelitian ini adalah Quick Ratio mengingat potensi kerusakan, keusangan, atau kehilangan pada persediaan sehingga tidak dapat digunakan untuk melunasi hutang ke kreditor. Makin kecil Quick Ratio maka semakin rendah kemampuan perusahaan dalam melunasi kewajiban lancarnya yang dapat berpengaruh pada kemampuan perusahaan melangsungkan usahanya di masa mendatang. Kondisi ini semakin meningkatkan kemungkian perusahaan menerima opini audit going concern. Hani dkk. (2003) menemukan bahwa rasio likuiditas memiliki pengaruh signifikan dan negatif pada penerimaan opini audit going concern.

$\mathbf{H}_{\mathbf{1}}$ : Likuiditas berpengaruh signifikan negatif pada penerimaan opini audit going concern.

\section{Pengaruh leverage pada opini audit going concern.}

Leverage, diproksikan dengan debt to equity ratio, menunjukkan proporsi atas penggunaan utang dibandingkan dengan penggunaan ekuitas dalam membiayai aktifitas perusahaan (Sartono, 2001). Semakin besar rasio leverage menyebabkan timbulnya keraguan atas kemampuan perusahaan untuk mempertahankan kelangsungan usahanya di masa depan karena sebagian besar dana yang diperoleh oleh perusahaan akan digunakan untuk membiayai utang dan dana untuk beroperasi akan semakin berkurang. Kreditor pada umumnya lebih menyukai leverage yang lebih rendah sehingga semakin besar peredaman dari kerugian yang dialami kreditor jika terjadi likuidasi. Semakin besar debtratio maka semakin besar kemungkinan perusahaan mendapatkan opini audit going concern. Masyitoh dan Adhariani (2010) dan Widyantari (2011) menyatakan bahwa leverage berpengaruh signifikan positif pada penerimaan opini audit going concern.

$\mathbf{H}_{2}$ : Leverage berpengaruh signifikan positif pada penerimaan opini audit going concern.

\section{Pengaruh profitabilitas pada opini audit going concern.}

Rasio profitabilitas mengukur tingkat efisiensi usaha. Semakin tinggi rasio profitabilitas maka semakin baik kinerja perusahaan dalam pengelolaan aset untuk menghasilkan laba sehingga dapat mempertahankan kelangsungan hidupnya. Semakin tinggi tingkat profitabilitas maka semakin rendah pula kemungkinan penerimaan opini audit going concern dan demikian pula sebaliknya (Komalasari, 2003).

$\mathbf{H}_{3}$ : Profitabilitas berpengaruh signifikan negatif pada penerimaan opini audit going concern.

\section{Pengaruh arus kas pada opini audit going concern.}

Ross, Westerfield dan Jafee (2001) dalam Masyitoh dan Adhariani (2010) menyatakan bahwa jika perusahaan memiliki kas yang 
memadai maka perusahaan dapat menghindarkan diri dari kegagalan untuk memenuhi kewajiban dan financial distress sehingga perusahaan diharapkan tidak menerima opini audit going concern. Penelitian Widyantari (2011) menemukan bahwa arus kas memiliki pengaruh yang signifikan negatif pada opini audit going concern.

$\mathbf{H}_{\mathbf{4}}$ : Arus kas berpengaruh signifikan negatif pada penerimaan opini audit going concern.

\section{Pengaruh ukuran perusahaan pada opini audit going concern.}

Penelitian terdahulu menemukan bahwa ada hubungan negatif antara ukuran perusahaan dengan penerimaan opini audit going concern. Mutchler et al. (1985) dalam Santosa dan Wedari (2007) menyatakan bahwa auditor lebih sering mengeluarkan opini audit going concern pada perusahaan kecil karena auditor mempercayai bahwa perusahaan besar dapat menyelesaikan keuangan yang dihadapinya daripada perusahaan kecil. Oleh karena itu semakin besar perusahaan maka semakin kecil potensi perusahaan menerima opini audit going concern.

$\mathbf{H}_{\mathbf{5}}$ : Ukuran perusahaan berpengaruh signifikan negatif pada penerimaan opini audit going concern.

\section{Pengaruh pertumbuhan perusahaan pada opini audit going concern.}

(Altman ; dalam Petronela, 2004) mengungkapkan bahwa perusahaan dengan negative growth mengindikasikan kecenderungan yang besar ke arah kebangkrutan. Kebangkrutan merupakan salah satu dasar bagi auditor untuk menentukan opini audit going concern sehingga perusahaan harus mampu mempertahankan keberlangsungan hidupnya. Dalam penelitian ini, pertumbuhan perusahaan diukur dengan rasio pertumbuhan penjualan karena rasio ini dapat mengukur seberapa baik perusahaan mempertahankan posisi ekonominya dalam industri maupun dalam kegiatan ekonomi secara keseluruhan (Setyarno et al. 2006). Penjualan yang terus meningkat memberikan peluang bagi perusahaan untuk meningkatkan labanya dan akan mengindikasikan rasio penjualan yang positif. Semakin tinggi rasio pertumbuhan penjualan perusahaan, akan semakin kecil kemungkinan auditor untuk menerbitkan opini audit going concern. Pertumbuhan perusahaan telah banyak dijadikan sebagai variabel dalam penelitian untuk mengukur pengaruhnya terhadap penerimaan opini audit going concern. Dalam penelitian yang dilakukan oleh Santosa dan Wedari (2007), terbukti bahwa pertumbuhan perusahaan berpengaruh negatif terhadap penerimaan opini audit going concern. Hasil yang sama juga ditemukan dalam penelitian Setyarno et al. (2006) dan pada penelitian Fanny dan Saputra (2005).

$\mathbf{H}_{\mathbf{6}}$ : Pertumbuhan perusahaan berpengaruh signifikan negatif pada penerimaan opini audit going concern.

\section{Pengaruh kualitas audit pada opini audit going concern.}

Angelo (1981) berpendapat bahwa auditor skala besar lebih independen sehingga memberikan kualitas audit yang lebih tinggi. Dan auditor skala besar memiliki insentif yang lebih untuk menghindari kritikan dan kerusakan reputasi dibandingkan auditor skala kecil. Auditor skala besar juga lebih cenderung untuk mengungkapkan masalah-masalah yang ada karena mereka lebih kuat untuk menghadapi resiko yang terjadi. Pendapat tersebut berarti bahwa auditor skala besar memiliki intense lebih untuk mendeteksi dan melaporkan masalah going concern. Penelitian yang dilakukan oleh Rusmin (2010) serta Hutchinson dan Leung (2007) menemukan bahwa auditor berkualitas tinggi lebih mungkin untuk mencegah praktik akuntansi yang dipertanyakan dan mendeteksi manajemen 
laba. Hal ini karena auditor berkualitas tinggi yang sering diproksikan dengan KAP Big-4 berusaha menjaga reputasinya untuk mempertahankan kualitas audit yang dihasilkan dan mengurangi risiko kerugian di masa yang akan datang.

$\mathbf{H}_{7}$ : Kualitas audit berpengaruh signifikan positif pada penerimaan opini audit going concern.

\section{Pengaruh Audit lag pada opini audit going concern.}

Menurut Januarti dan Fitrianasari (2008) audit lag mengindikasikan kemungkinan keterlambatan opini yang dikeluarkan dapat disebabkan oleh: (1) auditor lebih banyak melakukan pengujian; (2) manajemen mungkin melakukan negosiasi dengan auditor; (3) audior memperlambat pengeluaran opini dengan harapan manajemen dapat memecahkan masalah yang dihadapi, sehingga terhindar dari opini audit going concern. Louwers (1998), Lennox (2004), Indira dan Ella (2008), dan Putra (2010) menemukan pengaruh signifikan positif antara audit lag yang panjang dengan opini audit going concern. Hal ini dapat mengindikasikan bahwa semakin lama proses audit yang dilakukan berarti kemungkinan prosedur audit yang dilakukan semakin banyak dan berpengaruh ke hal yang material.

$\mathbf{H}_{\mathbf{8}}$ : Audit lag berpengaruh positif pada opini audit going concern.

\section{METODE PENELITIAN}

Analisis data dalam penelitian ini dilakukan dengan menggunakan regresi logistik karena variabel terikatnya yaitu opini audit going concern merupakan data kualitatif yang menggunakan variabel dummy dan variabel bebasnya merupakan kombinasi antara variabel metrik dan non-metrik (Ghozali, 2006). Penelitian ini menggunakan jenis data kuantitatif berupa data sekunder yang diperoleh dari Laporan Keuangan Tahunan dan Indonesian Capital Market Directory (ICMD). Kriteria yang dipertimbangkan dalam pengambilan sampel penelitian ini adalah sebagai berikut : (1) Perusahaan yang tercatat di BEI secara berturut-turut selama perioda pengamatan yaitu 2011 - 2013; (2) Perusahaan yang mengalami laba bersih negatif sekurangnya dua perioda laporan keuangan berturut-turut selama perioda pengamatan tahun $2011-2013$.

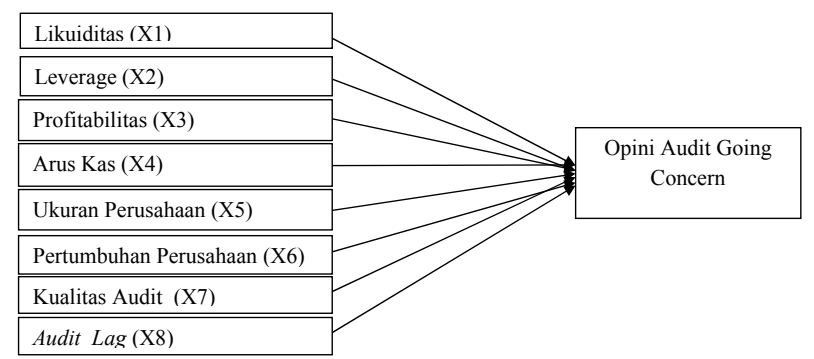

\section{Gambar 1 \\ Kerangka Konseptual}

\section{Definisi Operasionalisasi Variabel}

\section{Likuiditas}

Rasio likuiditas mengukur sejauh mana perusahaan mampu untuk menyelesaikan liabilitas jangka pendeknya dengan menggunakan asset lancar yang dimiliki (Sartono, 2009).

\section{Current Ratio $=$ Current Asset $/$ Current Liability}

\section{Leverage}

Rasio leverage diukur dengan menggunakan debt ratio yaitu membandingkan antara total liabilitas dengan total ekuitas (Sartono, 2009).

\section{Debt to Equity Ratio = Total Liability/Total Equity}




\section{Profitabilitas}

Profitabilitas adalah kemampuan perusahaan untuk menghasilkan pendapatan dari aktivitas utama yang dilakukan yang diukur dengan menggunakan rasio laba bersih sesudah pajak dibagi dengan total aset (Sartono, 2009).

ROA = Net Income After Tax/ Total Asset

\section{Rasio Arus Kas}

Arus kas dalam penelitian ini diukur dengan menggunakan cash flow to total debt ratio (Mills dan Yamamura, 1998).

\section{Cash Flow to Total Debt Ratio= Operating Cash Flow / Total Liability}

\section{Ukuran Perusahaan}

Ukuran perusahaan dalam penelitian ini diukur melalui logaritma total asset dengan mempertimbangkan bahwa nilai asset relatif lebih stabil dibandingkan dengan nilai market capitalized dan penjualan (Sudarmaji dan Sularto, 2007).

\section{Ukuran Perusahaan $=$ Ln $($ Total Aset $)$}

\section{Pertumbuhan Perusahaan}

Pertumbuhan perusahaan dalam penelitian ini diproksikan dengan rasio pertumbuhan penjualan (Setyarno dkk, 2006). Rasio pertumbuhan penjualan digunakan untuk mengukur kemampuan perusahaan dalam pertumbuhan tingkat penjualan dibandingkan tahun sebelumnya.

\section{Pertumbuhan Penjualan $=\left(\right.$ Penjualan $^{\mathrm{t}}-$ Penjualan $^{t-1}$ ) / Penjualan ${ }^{t-1}$}

\section{Kualitas Audit}

Kualitas audit diukur dengan menggunakan variabel dummy, yaitu diberikan kode 1 jika KAP berafiliasi dengan KAP Big 4, dan diberikan kode 0 jika tidak berafiliasi dengan KAP Big 4 (Setyarno dkk, 2006).

\section{Audit Lag}

Audit lag adalah jumlah hari antara tanggal tutup buku laporan keuangan sampai dengan tanggal opini laporan auditor independen (Lennox, 2002) yang mengindikasikan waktu penyelesaian audit yang dilakukan oleh auditor (Subyekti dan Widiyanti, 2004; Rachmawati, 2008).

\section{Opini Audit Going Concern}

Opini audit going concern merupakan opini audit modifikasi yang dalam pertimbangan auditor terdapat ketidakmampuan atau ketidakpastian signifikan atas kelangsungan hidup perusahaan di masa mendatang. Opini audit going concern diukur dengan menggunakan variabel dummy. Opini audit going concern diberi kode 1, opini audit nongoing concern diberi kode 0 .

\section{Metode Analisis Data}

Data penelitian ini diolah dengan menggunakan program SPSS (Statistical Package for Social Science) versi 16.0. Metode analisis yang digunakan adalah regresi logistik biner karena variabel dependen merupakan variabel dikotomi. Variabel dikotomi mewakili kemunculan atau tidaknya suatu kejadian yang biasanya diberikan angka 0 (nol) atau 1 (satu). Maka kategori angka $1=$ opini audit going concern dan $0=$ opini audit non-going concern.

Analisis regresi logistik biner digunakan untuk melihat pengaruh variabel independen, yaitu $\mathrm{X} 1, \mathrm{X} 2, \mathrm{X} 3, \ldots \mathrm{Xn}$ terhadap variabel dependen $\mathrm{Y}$ yang merupakan variabel respon biner yang hanya memiliki 2 (dua) nilai. Dalam analisis regresi logistik biner terdapat pula analisis dari Omnibus Test of Model Coefficients, uji kemampuan prediksi model, uji koefisien Nagelkerke R Square, dan uji Wald.

\section{Omnibus Test of Model Coefficients}

Omnibus Test of Model Coefficients dilakukan untuk menguji hipotesa bahwa 
memasukkan variabel independen kedalam model tidak akan menambah kemampuan prediksi model regresi logistik. Omnibus Test of Model Coefficients menggunakan nilai chi square goodness of fit dengan $\alpha=0,05$. Jika nilai $p$ value lebih kecil dari $\alpha=0,05$, maka hasil uji adalah signifikan. Sebaliknya, apabila nilai $p$ value lebih besar dari $\alpha=0,05$, maka hasil uji adalah tidak signifikan.

\section{Uji Kemampuan Prediksi Model}

Dalam uji ini ada 2 cara yang akan digunakan oleh peneliti, yaitu Hosmer and Lemeshow's Goodness of Fit Test dan Likelihood L. Hosmer and Lemeshow's Goodness of Fit Test menguji hipotesis nol bahwa data empiris cocok atau sesuai dengan model (tidak ada perbedaan antara model dengan data sehingga model dapat dikatakan fit). Suatu model dikatakan fit apabila nilai sig $>0.05$ pada Hosmer and Lemeshow's Goodness of Fit Test.

Hipotesis untuk menilai model fit adalah:

$\mathrm{H}_{0}$ : Model yang dihipotesakan fit dengan data

$\mathrm{H}_{1}$ : Model yang dihipotesakan tidak fit dengan data

Sedangkan untuk Likelihood L adalah probabilitas bahwa model yang dihipotesakan menggambarkan data input. Untuk menguji hipotesis nol dan alternatif, $L$ ditransformasikan menjadi -2logL. Statistik -2logL kadang-kadang disebut likelihood rasio $\mathrm{X}^{2}$ statistics, dimana $\mathrm{X}^{2}$ Distribusi dengan degree of freedom $\mathrm{n}-\mathrm{q}, \mathrm{q}$ adalah jumlah parameter dalam model.

\section{Uji Koefisien Nagelkerke R Square}

Uji koefisien dalam analisis logistik regresi biner menggunakan koefisien Nagelkerke $\mathrm{R}$ Square yang merupakan modifikasi dari koefisien dari Cox and Snell R Square agar nilai maksimumnya bisa mencapai satu dan mempunyai kisaran nilai antara 0 dan 1 , sama seperti koefisien R2 pada regresi linear berganda.
Nilai koefisien Nagelkerke R Square umumnya lebih besar dibandingkan Cox and Snell Square tapi cenderung lebih kecil dibandingkan dengn nilai determinasi R2 pada linear regresi berganda. Uji ini mengukur seberapa besar pengaruh variabel - variabel independen memengaruhi variabel dependen.

\section{Uji Wald}

Uji Wald digunakan untuk menguji seberapa besar hipotesa data diterima dan hipotesa yang digunakan dalam penelitian ini adalah apakah masing-masing variabel independen berpengaruh terhadap opini audit going concern yang merupakan variabel dependen. Dalam penelitian ini $\alpha=0,05$. Jika pvalue suatu variabel independen nilainya lebih kecil dari $\alpha=0,05$, maka koefisien regresi untuk variabel independen terhadap variabel dependen adalah signifikan. Sebaliknya, apabila nilai pvalue lebih besar dari $\alpha=0,05$, maka koefisien regresi untuk variabel independen terhadap variabel dependen adalah tidak signifikan. Model analisis yang digunakan untuk opini audit going concern, likuiditas, leverage, profitabilitas, cash flow ratio, ukuran perusahaan, pertumbuhan perusahaan, kualitas audit, audit lag adalah sebagai berikut:

$\operatorname{Ln} \frac{\pi}{(1-\pi)}=\beta_{0}+\beta_{1} X_{1}+\beta_{2} X_{2}+\beta_{3} X_{3}+\beta_{4} X_{4}+\beta_{5} X_{5}+\beta_{6} X_{6}+\beta_{7} X_{7}+\beta_{6} X_{6}$

Keterangan:

$\Pi$ adalah kemungkinan $\mathrm{Y}=1$

$\mathrm{Y}=1=$ opini audit going concern

$\mathrm{Y} \quad=0=$ opini audit non-going concern

$\beta=$ koefisien regresi

$\mathrm{X}_{1} \quad=$ Likuiditas

$\mathrm{X}_{2}=$ Leverage

$\mathrm{X}_{3}=$ Profitabilitas

$\mathrm{X}_{4}=$ Cash Flow Ratio

$\mathrm{X}_{5} \quad=$ Ukuran Perusahaan

$\mathrm{X}_{6}=$ Pertumbuhan Perusahaan

$\mathrm{X}_{7} \quad=$ Kualitas Audit

$\mathrm{X}_{8} \quad=$ Audit Lag 
Regresi logistik akan membentuk variabel prediktor/respon yang merupakan kombinasi linier dari variabel independen. Nilai variabel prediktor ini kemudian ditransformasikan menjadi probabilitas dengan fungsi logit. Regresi logistik juga menghasilkan odds ratio terkait dengan setiap nilai prediktor. Odds dari suatu kejadian diartikan sebagai probabilitas hasil yang muncul yang dibagi dengan probabilitas suatu kejadian yang tidak terjadi. Secara umum odds ratio merupakan peluang terjadinya suatu kejadian dibandingkan dengan peluang tidak terjadinya suatu kejadian. Rasio peluang bagi prediktor diartikan sebagai jumlah relatif dimana peluang hasil meningkat (rasio peluang $>1$ ) atau turun (rasio peluang $<1$ ) ketika nilai variabel prediktor meningkat sebesar 1 unit.

\section{HASIL PENELITIAN DAN PEMBAHASAN}

\section{Gambaran Umum Objek/Data Penelitian}

Penelitian ini menganalisis faktor-faktor yang memengaruhi penerimaan opini audit going concern perusahaan manufaktur yang tercatat (listed) di Bursa Efek Indonesia (BEI) yang telah go public pada periode 2011 hingga 2013. Kriteria yang digunakan adalah:

1. Perusahaan yang laporan keuangannya menerima Opini Audit Going Concern dari Kantor Akuntan Publik selama periode 2010 hingga 2013. Data diambil mulai dari tahun 2010, karena ada variabel yang menentukan hasil dari sampel tersebut di tahun berikutnya, yaitu pertumbuhan penjualan, atau

2. Perusahaan yang laporan keuangannya mengalami laba sebelum pajak negatif selama dua tahun berturut-turut selama periode penelitian tahun 2011-2013. Hal ini terkait dengan pendapat Mckeown et al.
(1991), yaitu auditor hampir tidak pernah memberikan opini audit going concern pada perusahaan yang mempunyai laba bersih setelah pajak positif.

Perusahaan yang menjadi sampel penelitian dan distribusi perusahaan menurut kategori industri.

\section{Tabel 1}

\section{Perusahaan Manufaktur berdasarkan kriteria pemilihan sampel}

\begin{tabular}{|c|c|l|}
\hline No. & Kode & Nama Perusahaan \\
\hline $\mathbf{1}$ & IKAI & PT Inti Keramik Alamasri Industri Tbk \\
\hline $\mathbf{2}$ & JKSW & PT Jakarta Kyoei Steel Works Tbk \\
\hline $\mathbf{3}$ & NIKL & PT Pelat Timah Nusantara Tbk \\
\hline $\mathbf{4}$ & BRPT & PT Barito Pacific Tbk \\
\hline $\mathbf{5}$ & TPIA & PT Chandra Asri Petrochemical Tbk \\
\hline $\mathbf{6}$ & AKKU & PT Alam Karya Unggul Tbk \\
\hline $\mathbf{7}$ & SIMA & PT Siwani Makmur Tbk \\
\hline $\mathbf{8}$ & FPNI & PT Lotte Chemical Titan Tbk \\
\hline $\mathbf{9}$ & SULI & PT SLJ Global Tbk \\
\hline $\mathbf{1 0}$ & TIRT & PT Tirta Mahakam Resources Tbk \\
\hline $\mathbf{1 1}$ & KBRI & PT Kertas Basuki Rachmat Indonesia Tbk \\
\hline $\mathbf{1 2}$ & MYTX & PTApac Citra Centertex Tbk \\
\hline $\mathbf{1 3}$ & ARGO & PT Agro Pantes Tbk \\
\hline $\mathbf{1 4}$ & POLY & PT Asia Pacific Fibers Tbk \\
\hline $\mathbf{1 5}$ & CNTX & PT Century Textile Industry Tbk \\
\hline $\mathbf{1 6}$ & DOID & PT Delta Dunia Makmur Tbk \\
\hline $\mathbf{1 7}$ & ESTI & PT Ever Shine Tex Tbk \\
\hline $\mathbf{1 8}$ & MYRX & PT Hanson International Tbk \\
\hline $\mathbf{1 9}$ & KARW & PT ICTSI Jasa Prima Tbk \\
\hline $\mathbf{2 0}$ & SSTM & PT Sunson Textile Manufacturer Tbk \\
\hline $\mathbf{2 1}$ & UNTX & PT Unitex Tbk \\
\hline $\mathbf{2 2}$ & BIMA & PT Primarindo Asia Infrastructure Tbk \\
\hline $\mathbf{2 3}$ & RMBA & PT Bentoel Internasional Investama Tbk \\
\hline
\end{tabular}


Tabel 2.

Tabel Persentase Distribusi Sektor Industri Manufaktur Menurut Kriteria

\begin{tabular}{|c|l|c|r|}
\hline No. & Jenis Sektor Manufaktor & Jumlah & Persentase \\
\hline $\mathbf{1}$ & Cement & 0 & $0 \%$ \\
\hline $\mathbf{2}$ & Ceramic, Glass, Porcelain & 1 & $4,17 \%$ \\
\hline $\mathbf{3}$ & Metal And Allied Products & 2 & $8,3 \%$ \\
\hline $\mathbf{4}$ & Chemicals & 2 & $8,3 \%$ \\
\hline $\mathbf{5}$ & Plastic \& Packaging & 3 & $12,5 \%$ \\
\hline $\mathbf{6}$ & Animal Feed & 0 & $0 \%$ \\
\hline $\mathbf{7}$ & Wood Industries & 2 & $8,3 \%$ \\
\hline $\mathbf{8}$ & Pulp \& Paper & 1 & $4,17 \%$ \\
\hline $\mathbf{9}$ & Automotive and & 0 & $0 \%$ \\
\hline $\mathbf{1 0}$ & Textile, Garment & 10 & $41,67 \%$ \\
\hline $\mathbf{1 1}$ & Footwear & 1 & $4,17 \%$ \\
\hline $\mathbf{1 2}$ & Cable & 0 & $0 \%$ \\
\hline $\mathbf{1 3}$ & Electronics & 0 & $0 \%$ \\
\hline $\mathbf{1 4}$ & Food and Beverages & 0 & $0 \%$ \\
\hline $\mathbf{1 5}$ & Tobacco Manufactures & 1 & $4,17 \%$ \\
\hline $\mathbf{1 6}$ & Pharmaceuticals & 1 & $4,17 \%$ \\
\hline $\mathbf{1 7}$ & Cosmetic and Household & 0 & $0 \%$ \\
\hline $\mathbf{1 8}$ & Houseware & 0 & $0 \%$ \\
\hline $\mathbf{T o t a l}$ & & 24 & $100 \%$ \\
\hline
\end{tabular}

Sumber: data diolah

Data mengenai opini audit going concern dan non-going concern

\section{Tabel 3}

Tabel Distribusi Perusahaan yang menerima opini audit Going Concern dan Non-Going Concern Tahun 2011-2013

\begin{tabular}{|l|l|l|l|l|}
\hline Tahun & $\mathbf{2 0 1 0}$ & $\mathbf{2 0 1 1}$ & $\mathbf{2 0 1 2}$ & $\mathbf{2 0 1 3}$ \\
\hline GC & 12 & 12 & 13 & 14 \\
\hline NGC & 12 & 12 & 11 & 10 \\
\hline Total & 24 & 24 & 24 & 24 \\
\hline
\end{tabular}

\section{Analisis Data.}

Penelitian ini menggunakan analisis logistic regression, yaitu regresi logistic biner (binary logistic regression) yang merupakan regresi logistik dimana variabel dependennya berupa variabel dikotomi atau variabel biner. Dalam analisis regresi logistic biner ini dilakukan uji wald untuk menguji apakah masing-masing koefisien regresi logistik signifikan atau tidak signifikan. Variabel dependen dalam penelitian ini adalah opini audit going concern, sedangkan variabel independen dalam penelitian ini adalah likuiditas, leverage, profitabilitas, cash flow ratio, ukuran perusahaan, pertumbuhan perusahaan, kualitas audit, dan audit lag.

\section{Omnibus Test of Model Coefficients}

Omnibus Test of Model Coefficients dilakukan untuk menguji hipotesa bahwa memasukkan variabel independen ke dalam model tidak akan menambah kemampuan prediksi model regresi logistik. Omnibus Test of Model Coefficients menggunakan nilai chi square goodness-of-fit dengan $\alpha=0,05$. Jika nilai $p$ value lebih kecil dari $\alpha=0,05$, maka hasil uji adalah signifikan. Sebaliknya, apabila nilai $p$ value lebih besar dari $\alpha=0,05$, maka hasil uji adalah tidak signifikan. Hasil uji statistik goodness of fit test model sebesar 32.840 dengan derajat kebebasan $=8$, dan nilai $p$-value sebesar 0.000 . Nilai $p$-value lebih kecil dari $\alpha=0.05$ sehingga dapat dinyatakan bahwa hasil uji ini signifikan. Kesimpulan dari pengujian ini adalah bahwa memasukkan variabel ke dalam model tidak akan menambah kemampuan prediksi model.

\section{Tabel 4}

Hasil Uji Omnibus Test of Model Coefficients

\begin{tabular}{|llrrc|}
\hline & & Chi-square & Df & Sig. \\
\hline Step 1 & Step & 32.840 & 8 & .000 \\
& Block & 32.840 & 8 & .000 \\
& Model & 32.840 & 8 & .000 \\
\hline
\end{tabular}

Sumber: hasil output SPSS 16.0 


\section{Uji Kemampuan Prediksi Model}

Dengan menggunakan Hosmer and Lemeshow's Goodness of Fit Test menguji hipotesis nol bahwa data empiris cocok atau sesuai dengan model (tidak ada perbedaan antara model dengan data sehingga model dapat dikatakan fit). Hipotesis untuk menilai model fit adalah:

$\mathrm{H}_{0}$ : Model yang dihipotesakan fit dengan data

$\mathrm{H}_{1}$ : Model yang dihipotesakan tidak fit dengan data

Tabel 5

Uji Hosmer dan Lemeshow

\begin{tabular}{|l|r|r|l|}
\hline Step & Chi-square & df & Sig. \\
\hline 1 & 9.048 & 8 & 0.338 \\
\hline
\end{tabular}

Sumber: hasil output SPSS 16.0

Tabel 5 menunjukkan hasil Hosmer and Lemeshow Goodness of Fit Test sebesar 9.048 dengan probabilitas signifikan 0.338 yang nilainya di atas 0.05 . Dengan demikian dapat disimpulkan bahwa $\mathrm{H}_{0}$ diterima dan sehingga dapat dikatakan bahwa model yang dihipotesakan fit dengan data.

Tabel 6

Matriks Klasifikasi

Classification Table ${ }^{\mathrm{a}}$

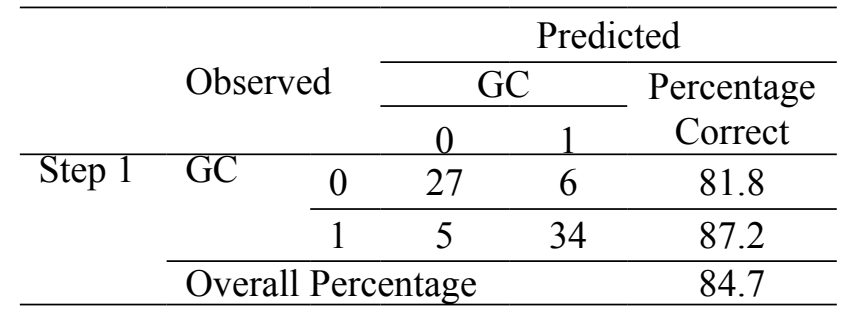

Sumber: hasil output SPSS 16.0

Tabel 6 menggambarkan prediksi bahwa peluang perusahaan tidak menerima kualifikasi opini going concern adalah sebanyak 27 perusahaan $(81.80 \%)$ dari total 33 perusahaan yang tidak menerima kualifikasi opini audit going concern. Sementara itu, peluang bagi perusahaan menerima kualifikasi opini audit going concern adalah sebanyak 34 perusahaan $(87.20 \%)$ dari total 39 perusahaan yang menerima kualifikasi opini going concern.

\section{Uji Ketepatan Model}

\section{Tabel 7}

Uji Ketepatan Model

\begin{tabular}{|c|c|c|c|}
\hline Step & $\begin{array}{c}-2 \text { Log } \\
\text { likelihood }\end{array}$ & $\begin{array}{c}\text { Cox \& Snell } \\
\text { R Square }\end{array}$ & $\begin{array}{c}\text { Nagelkerke } \\
\text { R Square }\end{array}$ \\
\hline $\mathbf{1}$ & $66.473^{\mathrm{a}}$ & 0.366 & 0.489 \\
\hline
\end{tabular}

Sumber: hasil output SPSS 16.0

Tabel 7 menginformasikan hasil uji ketepatan model dengan menggunakan Nagelkerke $R$ Square Test. Koefisien Nagelkerke R Square merupakan modifikasi dari koefisien Cox \& Snell $R$ Square untuk memastikan bahwa nilainya bervariasi dari 0 (nol) sampai 1 (satu). Tabel 4.7 (lihat Lampiran) menunjukkan hasil pengujian Nagelkerke $R$ Square yaitu sebesar 0.489 . Hal ini menunjukkan bahwa variabilitas variabel dependen yang dapat dijelaskan oleh variabilitas variabel independen sebesar $48.9 \%$ dan sisanya dijelaskan oleh faktor-faktor lain.

\section{Hasil Uji Hipotesis}

\section{Tabel 8}

Variables in the Equation-Wald Test

\begin{tabular}{|l|l|c|c|c|c|c|r|}
\hline & & B & S.E. & Wald & df & Sig. & Exp(B) \\
\hline Step 1 $^{\mathrm{a}}$ & LIK & -0.082 & 0.146 & 0.319 & 1 & 0.572 & 0.921 \\
\cline { 2 - 8 } & LEV & -0.164 & 0.060 & 7.570 & 1 & 0.006 & 0.849 \\
\cline { 2 - 8 } & PROF & -0.437 & 0.772 & 0.321 & 1 & 0.571 & 0.646 \\
\cline { 2 - 8 } & CFR & -0.343 & 1.765 & 0.038 & 1 & 0.846 & 0.709 \\
\cline { 2 - 8 } & UP & -0.284 & 0.192 & 2.189 & 1 & 0.139 & 0.752 \\
\cline { 2 - 8 } & PP & 0.064 & 0.541 & 0.014 & 1 & 0.906 & 1.066 \\
\cline { 2 - 8 } & KA & -1.566 & 0.698 & 5.032 & 1 & 0.025 & 0.209 \\
\cline { 2 - 8 } & AL & 0.034 & 0.026 & 1.610 & 1 & 0.204 & 1.034 \\
\cline { 2 - 8 } & Constant & 6.420 & 5.573 & 1.327 & 1 & 0.249 & 613.816 \\
\hline
\end{tabular}

Sumber: Hasil output SPSS 16.0

Tabel 8 hasil uji statistik menunjukkan nilai signifikansi dari seluruh variabel yang diteliti. Data tersebut menunjukkan bahwa variabel yang 
tidak memiliki pengaruh yang signifikan pada penerimaan opini audit going concern adalah variabel likuiditas (p-value sebesar 0,572), variabel profitabiiltas ( -value 0,571), variabel cash flow to debt ratio ( $p$-value sebesar 0.846), variabel ukuran perusahaan ( $p$-value sebesar 0.139), variabel pertumbuhan perusahaan ( $p$-value sebesar 0.906), dan variabel audit lag ( $p$-value sebesar 0.204). Sementara itu variabel yang memiliki pengaruh pada penerimaanopini audit going concern adalah variabel leverage ( $\mathrm{p}$-value sebesar 0,006), variabel kualitas audit (p-value sebesar 0.025)

\section{Model Regresi Logistik.}

Setelah melakukan uji hipotesis dengan menggunakan uji Wald, maka berikut ini merupakan model yang dihasilkan dari pengujian tersebut:

$\operatorname{Ln} \frac{\pi}{1-\pi}=6.420-0.082 \mathrm{LIK}-0.164 \mathrm{LEV}-0.437 \mathrm{PROF}-0.343 \mathrm{CPR}-0.284 \mathrm{UP}+0.064 \mathrm{PP}$ $-1.566 \mathrm{KA}+0.034 \mathrm{AL}$

Dimana:

$\operatorname{Ln} \frac{\pi}{1-\pi}=$ Penerimaan opini audit going concern

LIK = Likuiditas

$\mathrm{LEV}=$ Leverage

PROF $=$ Profitabilitas

$\mathrm{CFR}=$ Cash flow to debt ratio

UP = Ukuran Perusahaan

$\mathrm{PP} \quad=$ Pertumbuhan Perusahaan

$\mathrm{KA}=$ Kualitas Audit

$\mathrm{AL}=$ Audit lag

\section{Pembahasan}

\section{Pengaruh Likuiditas pada Penerimaan Opini Audit Going Concern}

Berdasarkan hasil pengujian diketahui bahwalikuiditas tidak memiliki pengaruh terhadap opini audit going concern. Hasil penelitian ini tidak sejalan dengan penelitian Bruynseels dan Willekens (2006) yang menunjukkan bahwa likuiditas memiliki pengaruh yang signifikan pada penerimaan opini audit going concern. Meskipun demikian hasil penelitian ini sejalan dengan penelitian Rahayu (2007), Susanto (2009), Masyitoh dan Adhariani (2010), Muttaqin (2012), yang menunjukkan bahwa rasio likuiditas tidak memiliki pengaruh signifikan pada penerimaan opini audit going concern.

\section{Pengaruh Leverage pada Penerimaan Opini Audit Going Concern}

Berdasarkan hasil pengujian variabel leverage memiliki pengaruh yang signifikan negative terhadap penerimaan opini audit going concern pada perusahaan yang tercatat di Bursa Efek Indonesia. Penelitian ini tidak sejalan dengan penelitian Erwin (2006) serta Rahman dan Siregar (2012) yang menyatakan bahwa leverage memiliki pengaruh yang signifikan positif pada penerimaan opini audit going concern. Penelitian ini sejalan dengan penelitian Setiawan dan Suryono (2015) yang menemukan pengaruh negative leverage pada penerimaan opini audit going concern. Hasil ini menunjukkan bahwa rasio leverage yang tinggi justru menunjukkan kinerja perusahaan yang baik sehingga kreditor memiliki kepercayaan yang tinggi dan bersedia memberikan kredit yang besar pada perusahaan.

\section{Pengaruh Profitabilitas pada Penerimaan Opini Audit Going Concern}

Berdasarkan hasil pengujian variabel profitabilitas tidak memiliki pengaruh terhadap penerimaan opini audit going concern pada perusahaan yang tercatat di Bursa Efek Indonesia. Penelitian ini tidak sejalan dengan penelitian Muttaqin (2012), Behn et al. (2001) yang menemukan bahwa profitabilias ini berpengaruh signifikan dan negatif dalam memprediksi opini going concern. Namun demikian, penelitian ini sejalan dengan penelitian Hani dkk. (2003) dan Rahayu (2007) yang menemukan bahwa rasio profitabilitas tidak berpengaruh signifikan pada penerbitan opini audit going concern. 
Pengaruh Cash Flow to Debt Ratio pada Penerimaan Opini Audit Going Concern

Berdasarkan hasil pengujian variabel cash flow to debt ratio tidak memiliki pengaruh yang signifikan terhadap penerimaan opini audit going concern pada perusahaan yang tercatat Bursa Efek Indonesia. Penelitian ini tidak sejalan dengan penelitian Mutchler (1985) serta Mills dan Yamamura (1998) yang menyatakan bahwa cash flow to total debt ratio mampu memprediksi opini audit going concern yang diberikan auditor. Namun demikian, penelitian ini sejalan dengan penelitian Masyitoh dan Adhariani (2010) yang justru menemukan bahwa cash flow to total debt ratio tidak berpengaruh signifikan pada opini audit going concern.

\section{Pengaruh Ukuran Perusahaan pada Penerimaan Opini Audit Going Concern}

Berdasarkan hasil pengujian ukuran perusahaan tidak memiliki pengaruh yang signifikan terhadap penerimaan opini audit going concern pada perusahaan yang tercatat Bursa Efek Indonesia. Penelitian ini tidak sejalan dengan penelitian Indriani (2005) dalam Rachmawati dan Triatmoko (2007) yang menyatakan bahwa perusahaan dengan total aset besar besar relatif lebih stabil dan lebih mampu menghasilkan laba dibanding perusahaan dengan total aset kecil sehingga cenderung lebih mampu untuk menyelesaikan masalah keuangan yang dihadapi dan mempertahankan kelangsungan usahanya. Penelitian ini juga tidak sejalan dengan (Kevin et al., 2006) yang menyatakan bahwa perusahaan besar memiliki kemampuan yang lebih baik dalam mempertahankan kelangsungan hidupnya bahkan ketika perusahaan mengalami financial distress sehingga untuk perusahaan besar auditor akan menunda untuk mengeluarkan opini audit going concern dengan harapan bahwa perusahaan akan dapat mengatasi kondisi buruk pada tahun mendatang.
Namun demikian, penelitian ini sejalan dengan hasil penelitian Kristiana (2012), Januarti dan Fitrianasari (2008), serta Ramadhany (2005) yang menemukan bahwa ukuran perusahaan tidak berpengaruh signifikan pada penerimaan opini audit going concern. Penolakan hipotesis ini mungkin dikarenakan ukuran perusahaan tidak menjadi patokan dalam penerimaan opini audit going concern. Hal ini sesuai dengan penelitian Praptitorini dan Januarti (2007) yang menyatakan bahwa kelangsungan hidup usaha selalu dihubungkan dengan kemampuan manajemen dalam mengelola perusahaan. Dengan demikian meskipun sebuah perusahaan tergolong dalam perusahaan kecil, namun jika perusahaan tersebut memiliki manajemen dan kinerja yang baik maka perusahaan mampu bertahan dalam jangka panjang dan terhindar dari penerimaan opini audit going concern.

\section{Pengaruh Pertumbuhan Perusahaan pada Penerimaan Opini Audit Going Concern}

Berdasarkan hasil pengujian pertumbuhan perusahaan memiliki pengaruh yang signifikan terhadap penerimaan opini audit going concern pada perusahaan yang tercatat Bursa Efek Indonesia. Penelitian ini tidak sejalan dengan penelitian Kristiana (2012) dan Altman (1968) yang menyatakan bahwa pertumbuhan perusahaan mengindikasikan kemampuan perusahaan dalam mempertahankan kelangsungan usahanya dan bila perusahaan mengalami negative growth maka hal itu mengindikasikan kecenderungan yang lebih besar ke arah kebangkrutan. Namun demikian, penelitian ini sejalan dengan penelitian Fanny dan Saputra (2005) serta Setyarno dkk. (2006) yang menemukan bahwa pertumbuhan perusahaan tidak berpengaruh signifikan pada penerimaan opini audit going concern.

\section{Pengaruh Kualitas Audit pada Penerimaan Opini Audit Going Concern}

Berdasarkan hasil pengujian kualitas audit memiliki pengaruh yang signifikan negatif 
terhadap penerimaan opini audit going concern pada perusahaan yang tercatat di Bursa Efek Indonesia. Penelitian ini tidak sejalan dengan penelitian Rusmin (2010) serta Hutchinson dan Leung (2007) namun sejalan dengan penelitian Komalasari (2004) dan Tamba (2009). Penelitian tersebut menunjukkan bahwa KAP besar, yang dinilai melaksanakan audit yang berkualitas, tidak lebih banyak menerbitkan laporan going concern dibandingkan KAP yang lebih kecil. Tamba (2009) menjelaskan kemungkinan hasil tersebut terjadi karena manajer perusahaan yang rasional tidak memilih auditor yang berkualitas tinggi dan membayar biaya yang tinggi apabila kondisi perusahaan sedang tidak baik. Hal ini didasari oleh anggapan yang menyebutkan bahwa auditor kualitas yang tinggi yang berada pada KAP besar mampu mendeteksi kondisi perusahaan yang buruk dan menyampaikannya kepada publik.

\section{Pengaruh Audit Lag pada Penerimaan Opini Audit Going Concern}

Berdasarkan hasil pengujian audit lag tidak memiliki pengaruh yang signifikan terhadap penerimaan opini audit going concern pada perusahaan yang tercatat di Bursa Efek Indonesia. Penelitian ini tidak sejalan dengan Indira dan Ella (2008), dan Cahyadi (2010) yang menyatakan ada hubungan positif antara audit lag yang panjang dengan opini audit going concern. Namun demikian, penelitian ini konsisten dengan Januarti (2009), Surbakti (2011), Widyantari (2011) audit lag tidak berpengaruh terhadap penerimaan opini going concern. Penelitian ini menunjukkan bahwa lamanya proses audit yang dilakukan oleh auditor belum tentu mengindikasikan bahwa suatu perusahaan tersebut mengalami masalah dalam pelunasan hutang, masalah likuidasi, adanya gugatan dari pihak ketiga yang dapat menyebabkan perusahaan dibangkrutkan, dan berbagai kondisi lainnya sehingga auditor harus memberikan opini audit going concern. Lamanya proses audit bisa saja disebabkan oleh kompleksitas bisnis perusahaan, banyaknya transaksi yang melibatkan mata uang asing, kompleksitas dalam pencatatan transaksi dalam perusahaan, dan hal-hal lain yang tidak berhubungan dengan kemampuan perusahaan dalam melangsungkan kegiatan usahanya.

\section{KESIMPULAN DAN SARAN}

\section{Kesimpulan}

Penelitian ini menunjukkan bahwa leverage memiliki pengaruh negative dan kualitas audit memiliki pengaruh yang signifikan pada penerimaan opini audit going concern, sedangkan likuiditas, profitabilitas, ukuran perusahaan, rasio arus kas, pertumbuhan perusahaan, dan audit lag tidak memiliki pengaruh yang signifikan pada penerimaan opini audit going concern.

\section{Saran}

Penelitian selanjutnya dapatmenggunakan klasifikasi perusahaan yang mengalami rugi bersih selama 3 tahun berturut-turut sehingga lebih menggambarkan tekanan pada kondisi keuangan yang memengaruhi penerimaan opini audit going concern oleh perusahaan. Penelitian selanjutnya dapat menggunakan variabel lain, seperti cash flow to assets dan debt default yang mungkin memengaruhi penerimaan opini audit going concern.

\section{DAFTAR PUSTAKA}

Behn, Bruce K., Steven E. Kaplan, and Kip R. Krumwiede. 2001. Further Evidence on the Auditor's Going-Concern Report: The Influence of Management Plans. Auditing: A Journal of Practice \& Theory, Vol. 20(1)

Belkaoui, Ahmed R. 2006. Teori Akuntansi. Edisi Terjemahan. Jilid 1. Jakarta: Salemba Empat. 
Bruynseels, Liesbeth and M. Willekens. 2006. Strategic Viability and Going-Concern Audit Opinion. Available at: http:// www. Placement. abs. aston.ac.uk/ newweb/ Academic Groups/fal/ASIG/ Bruynseels_Willekens_BAA.pdf.

Chen, K.Y., K., Lin and J., Zhou, 2005. Audit quality and earnings management for Taiwan IPO firms. Managerial Auditing Journal, Vol. 20(1).

DeAngelo, Linda Elizabeth. 1981. Auditor Size and Audit Quality. Journal of Accounting and Economics, Vol. 3.

Fanny, M., dan Sylvia, S., 2005, Opini Audit Going Concern: Kajian Berdasarkan Model Prediksi Kebangkrutan, Pertumbuhan Perusahaan, Dan Reputasi Kantor Akuntan Publik (Studi Pada Emiten Bursa Efek Jakarta), Simposium Nasional Akuntansi VIII, September.

Ghozali, Imam. 2006. Aplikasi Analisis Multivariate dengan Program SPSS. Semarang: Badan Penerbit Universitas Diponegoro.

Hani, Clearly, dan Mukhlasin, 2003. GoingConcern dan Opini Audit: Suatu Studi Pada Perusahaan Perbankan di BEJ. Makalah Disampaikan dalam Simposium Nasional Akuntansi VI. Surabaya.

Husnan, Suad, dan Enny Pudjiastuti. 2006. Dasar-dasar Manajemen Keuangan. Edisi Kelima. Yogyakarta: UPP STIM YKPN.

Ikatan Akuntan Publik Indonesia. 2013. Standar Profesional Akuntan Publik. Jakarta: Salemba Empat.

Januarti, Indira. 2009. Analisis Pengaruh Faktor Perusahaan, Kualitas Auditor, Kepemilikan Perusahaan terhadap Pemberian Opini Audit Going concern (Perusahaan Manufaktur yang Tercatat di Bursa Efek Indonesia). Makalah
Disampaikan dalam Simposium Nasional Akuntansi XII. Palembang.

Januarti, Indira dan Ella Fitrianasari. 2008. Analisis Rasio Keuangan dan Rasio Nonkeuangan yang Memengaruhi Auditor dalam Memberikan Opini Audit Going Concern pada Auditee (Studi Empiris pada Perusahaan Manufaktur yang Tercatat di BEJ 2000-2005). Jurnal MAKSI, Vol. 8 (1).

Jensen, M.C., and W.H. Meckling. 1976. Theory of The Firm: Managerial Behaviour Agency Cost and Ownership Structure. Journal of Financial Economics, Vol. 3(4).

Kevin, C.K. Lam, and Yaw M. Mensah. 2006. Auditor's Decision Making Under Going-Concern Uncertainties in Low Litigation-Risk Environments: Evidence from Hong Kong. Available at: http://papers.ssrn.com/sol3/papers. cfm?abstract_id=899323.

Komalasari, A.A. (2004). Analisis Pengaruh Kualitas Auditor dan Proxi Going Concern Terhadap Opini Auditor. Jurnal Akuntansi dan Keuangan, Vol. 9(2).

Kristiana, Ira. 2012. Pengaruh Ukuran Perusahaan, Profitabilitas, Likuiditas, Pertumbuhan Perusahaan terhadap Opini Audit Going Concern Perusahaan Manufaktur yang terdaftar di Bursa Efek Indonesia (BEI). Jurnal Mahasiswa Akuntansi, Vol.1 (2).

Lennox, Clive S. 2002. Going-concern Opinions in Failing Companies: Auditor Independence and Opinion Shopping. Available at: http://papers.ssrn.com/ sol3/papers.cfm? abstract_id=240468.

Masyitoh, Oni Currie and Desi Adhariani. 2010. The Analysis of Determinants of Going concern Audit Report. Journal of Modern Accounting and Auditing, Vol. 6(4).

Mills, John R., and Jeanne H. Yamamura. 1998. The Power of Cash Flow Ratio. Journal of Accountancy. October. 
Mutchler, Jane F. 1985. A Multivariate Analysis of the Auditor's Going concern Decision. Journal of Accounting Research, Vol. 23(2).

Muttaqin, Ariffandita Nuri. 2012. Analisis Pengaruh Rasio Keuangan dan Non Keuangan terhadap Penerimaan Opini Audit Going Concern (Studi Empiris pada Perusahaan Manufaktur yang terdaftar di BEI Tahun 2010). Jurnal Akuntansi, Vol.1(2).

Praptitorini, Mirna Dyah dan Indira Januarti. 2007. Analisis Pengaruh Kualitas Audit, Debt Default, dan Opinion Shopping terhadap Pemberian Opini Going Concern. Makalah Disampaikan dalam Simposium Nasional Akuntansi X. Makassar.

Putra, I Gede Cahyadi. 2010. Opini Audit Going Concern: Kajian Berdasarkan Prediksi Kebangkrutan dan Auditor Independen. Tesis. Universitas Udayana, Bali.

Rachmawati, Andri dan Hanung Triatmoko. 2007. Analisis Faktor-Faktor yang Memengaruhi Kualitas Laba dan Nilai Perusahaan. Makalah Disampaikan dalam Simposium Nasional Akuntansi $X$. Makassar.

Rachmawati, Sistya. 2008. Pengaruh Faktor Internal dan Eksternal Perusahaan Terhadap Audit Delay dan Timeliness. Jurnal Akuntansi dan Keuangan, Vol.10 (1).

Rahayu, Puji. 2007. Assessing Going concern Opinion: A Study Based on Financial and Non-Financial Information. Makalah Disampaikan dalam Simposium Nasional Akuntansi X. Makassar.

Ramadhany, Alexander. 2004. Analisis Faktorfaktor yang Memengaruhi Pemberian Opini Going Concern pada Perusahaan Manufaktur yang Mengalami Financial Distress di Bursa Efek Jakarta. Tesis. Universitas Diponegoro, Semarang.
Ross, Stephen, R. W. Westerfield, and J. Jaffe. 2002. Corporate Finance. McGrawHill: New York.

Sartono, R. Agus. 2009. Manajemen Keuangan Teori dan Aplikasi. Edisi 4. Yogyakarta: BPFE.

Setiawan, Feri dan Bambang Suryono. (2015). Pengaruh pertumbuhan perusahaan, profitabilitas, likuiditas, dan leverage terhadap opini audit going concern. Jurnal Ilmu dan Riset Akuntansi, Vol.4 (3).

Setyarno, Eko Budi, Indira Januarti, dan Faisal. 2006. Pengaruh Kualitas Audit, Kondisi Keuangan Perusahaan, Opini Audit Tahun Sebelumnya, Pertumbuhan Perusahaan terhadap Opini Audit Going Concern. Makalah Disampaikan dalam Simposium Nasional Akuntansi IX. Padang.

Susanto, Yulius Kurnia.2009. Faktor-faktor yang Mempengaruhi Penerimaan Opini Audit Going Concern pada Perusahaan Publik Sektor Manufaktur. Jurnal Bisnis dan Akuntansi, Vol.11 (3).

Tamba, R. U. B., dan Hasan S. S., 2009, Pengaruh Debt Default, Kualitas Audit, dan Opini Audit terhadap Penerimaan Opini Going Concern pada Perusahaan Manufaktur yang Terdaftar di Bursa Efek Indonesia. Diakses dari http://akuntansi.usu.ac.id/ jurnal-akuntansi-4.html.

Widyantari, Putri A.A. Ayu. 2011. Opini audit going concern dan faktor-faktor yang memengaruhi: studi pada perusahaan manufaktur di Bursa Efek Indonesia. Tesis. Program Pasca Sarjana. Universitas Udayana. Diakses dari http://www.pps.unud.ac.id/ thesis pdf thesis/unud-790-tesisputriwidyantari. pdf. 